THE ANNALS OF "DUNAREA DE JOS" UNIVERSITY OF GALATI

FASCICLE XV ISSN - 1454 - 9832 - Vol. 2/2019

Article DOI: https://doi.org/10.35219/efms.2019.2.10

\title{
PREPARATION OF PERFORMANCE SWIMMERS AT SPRINT DISTANCES
}

\author{
Natalia STEPANOVA, \\ $\mathrm{PhD}$ in Pedagogic Sciences, university lecturer, $\boldsymbol{G} \boldsymbol{V} \boldsymbol{V} \boldsymbol{S}$, USFEFS, \\ stepanova_natalia65@mail.ru \\ Sergey POSTICA, \\ 11, Chisinau, Republic of Moldova
}

Coach emeritus of the RM, director of the specialized Sports School of swimming and football No.

\begin{abstract}
Summary:Determination of effective tools and methods for improving the fastness of the swimmers in modern development.
\end{abstract}

Keywords: tools, methods, training swimmers.

\section{News}

Under the current conditions, when the tendency to match the mastery of the best athletes from different countries is found, the problems of perfecting technical training are often presented quite frequently. With the rise of the prestige of sport, the role of multilateral training grows continuously. The basic significance of multilateral training is to increase the sporting result at sprint distances, which is an integral indicator of technical, functional training, etc.

Perfecting the instructional and educational process of swimming is an important concern for many authors.

In the present conditions of the increase in a sporting performance in swimming, it is necessary that specializes in the field find new methods, related to the main elements of structure - competition and training, in the composition of which a large number of components enter [ 1.5$]$.

In the modern practice of preparing performance athletes, there are different schemes and variants of proximity to the main competitions, which are used successfully. The most used approach in world practice is characterized by the fact that the main qualifying competitions (national Championship) take place 4-3 weeks before the start of the main stages. In this case, athletes perform the basic efforts ahead of the country's championship. After the competitions have given lasted, for 10-14 days, workouts are carried out in a volume of $20-30 \%$ of the limit values, based on the structure of the pre-competitive mesocycle.

In this context, training planning has become a "reserved" tool for coaches who have a very clear vision of the training ensemble and who know how to solve the requirements of high-performance sporting training, directing the entire Process to achieve special results. [2, 3.6].
The issue of the pre-competitive period in preparation planning may be:

- selection of competitions to which they are attended;

- their staggering in the preparation plan;

- planning methods and means of training according to competitions;

- maintaining the body of athletes at a high functional level, in such a way that performance fluctuations are relatively small;

- setting a high working rhythm (e.g. 3 weeks growing +1 week with lower volume and intensity);

- planning of "on-the-go" competitions and one or two preparatory peaks $[4,7]$.

All these problems can be solved, only in the situation of logical thinking, coherent in the elaboration of training, thinking materialized in the preparatory plans.

The purpose of the research is the elaboration of the special exercise complex, geared to increase the speed of swimming in the training of Brassists, which will help to achieve the maximum level of the sporting result in the main competitions of $\mathrm{Of}$ the season, i.e. the exit to the "age" of personal sporting successes.

\section{Research Objectives}

1. The theoretical approach to the manner and content of the preparation of swimholders based on thestudy of literature;

2. Analysis of the method of planning the training process of the brassists during the pre-competition stage.

\section{ResearchMethods}

In there search, there were used the methods, which had the purpose of verifying different aspects of the preparation, in accordance with the current requirements of the sport, namely: 


\section{THE ANNALS OF "DUNAREA DE JOS" UNIVERSITY OF GALATI \\ FASCICLE XV ISSN - 1454 - 9832 - Vol. 2/2019}

1. Analysis and generalization of document data from the literature.

2. Pedagogic observation.

3. Method of testing.

4. Statistical-mathematical processing method.

The training in the gym was of a strict character.-

- On Monday-Thursday, general physical Training (PFG) work outs were conducted.

- On Tuesday - Friday - rubber band Exercises.

- OnWednesday-Saturday-the force room. It is compulsory the distribution of various groups of muscles in different days, as an example:

- On Tuesday it is planned training witha rubber band, and months PFG for torso muscles.

-On Wednesday - The force room with an emphasis on the leg muscles. -On Thursday - PFG for mobility (medical ball, reaction, and...)

- On Friday - Rubber Band;

- Saturday - Exercises in the force room with different equipment, dumbbell, but with the exception of the muscles responsible for the rowing .

Similarly, exercises on fitness (fitball) are applied, where virtually all muscle groups are included, and it is of major importance that these exercises are oriented to the identification and maintenance of the center of body weight.

The exercises in water were structured in such a way as to take place the transfer of $50 \%$ in the pool of that quality, on the development of which it worked in the hall. In the water, three weeks until the competitions, two times in the week the swimming with the brake belt in the joint is carried out with different exercises. During the odd days, there were performed series for the development of resistance, and in the days it appears in the workouts apply the swimming on the leash with the maintenance of 15-20s speed, from the total time of training within the limits of 15-20 min.

Elementary speed manifestations, as well as swimming technique are positive references for the development of the athlete's speed capacity.

The contemporary method of increasing the speed of the swimmer in general lines leads to the following situations:

-With the increase in the speed of swimming, the technique suffers considerable changes (by character, amplitude, coordination of movements, etc.);

-The main difficulties in increasing the speed of swimming are related to the automation of movements in the water, which occurs during multiple repetitions of the exercises, performed in a single tempo (table 1).

Table 1. Water speed exercises applied to the preparation of swimfighters in the training of brassistants

\begin{tabular}{|c|c|c|c|}
\hline Rehearsal No. Number of rest series & $\begin{array}{c}\text { Number of } \\
\text { replay }\end{array}$ & $\begin{array}{c}\text { Number of } \\
\text { series }\end{array}$ & $\begin{array}{c}\text { between } \\
\text { series }\end{array}$ \\
\hline Swimming in series $10-25 \mathrm{~m}$ from start with maximum speed & $4-6$ & $1-2$ & $30-60$ \\
\hline $\begin{array}{l}\text { Swimming on distances of } 50-100 \mathrm{~m} \text { from start with } \\
\text { acceleration: } 15-20 \mathrm{~m} \text { with maximum visor, } 30-35 \mathrm{~m} \\
\text { compensatory speed }\end{array}$ & $3-4$ & $1-2$ & $45-90$ \\
\hline $\begin{array}{l}25 \mathrm{~m} \text { long distance swimming with respiration: no breathing, } \\
1-4 \text { inputs }\end{array}$ & $3-4$ & $1-2$ & $45-90$ \\
\hline $\begin{array}{l}25 \mathrm{~m} \text { long swimming with rubber paws at maximum speed, } \\
\text { holding breath and breathless }\end{array}$ & $4-6$ & $1-2$ & $45-90$ \\
\hline $\begin{array}{l}\text { Accelerated swimming on distances of } 100 \mathrm{~m} \text { with floats: } 15- \\
20 \mathrm{~m} \text { with maximum speed, } 30-35 \mathrm{~m} \text { with a countervailing } \\
\text { speed }\end{array}$ & $3-6$ & - & $120-180$ \\
\hline $\begin{array}{l}\text { Swimming with the application of the elastic damper in one } \\
\text { direction and back }\end{array}$ & $5-10$ & $1-2$ & $30-60$ \\
\hline $\begin{array}{l}\text { Swimming in distances of } 10-25 \mathrm{~m} \text {, the maximum speed with } \\
\text { the help of arms, legs in different complexes of exercises of } \\
\text { hands, feet ,and respiration }\end{array}$ & $4-6$ & $2-3$ & $30-60$ \\
\hline
\end{tabular}

The effectiveness of the speed training depends on the intensity of the exercise, the ability of thes wimmer to mobilize, name lytheability of the swimmer, in the training process, to perform the speed drills in a borderline and sub-limit, as soon as possible in order to breakpersonal records, to serve as excitablefactors in increasing the training speed.

The analysis of the process of preparation of performance swimmers in a training macrocycle has highlighted the specifics of individualized planning for each athlete. In this context, the methodology of the 


\section{THE ANNALS OF "DUNAREA DE JOS" UNIVERSITY OF GALATI}

FASCICLE XV ISSN - 1454 - 9832 - Vol. 2/2019

application of the means focused on the development of the speed at the pre-competition stage was analyzed in order to establish the transfer of this workload to the sporting result, which will be shown in the Peak competitions (table 2).

Table 2. The best results of the Brassishets

\begin{tabular}{|c|c|}
\hline \multicolumn{2}{|c|}{ MIS Chişca Tatiana, year of birth 1995} \\
\hline$\%$ & $\begin{array}{l}\text { European Swimming Championship } 2018 \text { in Glasgow (United Kingdom), 50m pool: } \\
\text { 50bras-31.49 (13th place, semifinalist),100bras-1, 09, } 31 \text { - New National Record; } \\
\text { qualification for the World Championship in Korea and the World Universiade in Italy; } \\
\text { Double Champion, cup holder after a FINE score at the International Swimming } \\
\text { Tournament Nioveia Grand Prix 2018, Thessaloniki (Greece); } \\
\text { Double Champion at the International Championship of Ukraine 2019, Kharkov }\end{array}$ \\
\hline & Pcela Nicolae, year of birth 2004; \\
\hline $\begin{array}{l}* \\
* \\
*\end{array}$ & $\begin{array}{l}\text { Master of Sport; } \\
\text { Recordman and Champion of the junior R. Moldova Championship; } \\
\text { Silver medalist at the senior R. Moldova Championship; } \\
\text { Triple Champion and former at the } 2018 \text { international swimming tournament in Burgas } \\
\text { (Bulgaria); } \\
\text { Silver medalist at the Sprint International Swimming tournament 2018, Anyksciai } \\
\text { (Lithuania); } \\
\text { awarded the bronze medal at the distance of } 50 \mathrm{~m} \text { bras at the International Championship of } \\
\text { Romania 2019, Bucharest. }\end{array}$ \\
\hline
\end{tabular}

\section{Conclusions}

1. The bras process has evolved over the years, thanks to the changes in the technique to which multiple research has contributed to the theory and practice level.

2. However, in the practice of preparing swimkeepers, the need to perform the exercises at the sublimit level is often ignored and replaced by the highspeed volume, with the intensity, which significantly succumbed.

3. The level of manifestation of speed qualities during training depends on the selection of the means and methods, which would allow for the coverage of the limit manifestations. Here it is effective to use various means of preventive stimulation of the working capacity (pedagogical, physical, psychological), their use both separate and complex.

4. The duration of completion of the exercises in the process of speed development is determined by individual particularities and the need to ensure a high level of speed capacities.

\section{Bibliography}

1. Maglishco E. W. Let's swim faster. Bucharest, 1992, $288 \mathrm{p}$.

2. Rîșneac B., Solonenco G. Methodic Training and training in the natsation. Chisinau: Totex-Lux, 2017, 223 p. 3. Stepanova Natalia, Postica Sergiu. Efficiency of methods and means of improvement of return to swimming. Magazine "theory and Art of Physical Education in school" 3/2015, Chişinău, P. 66-69.

4. Nechunavaev i. P. swimming. Book-Trainer. Moscow: EKMO, 2012, 274
5. Platonov v. N. Sport Swimming. The way to success. Book I, II Kiev, Olympic literature, 2011, book I, II, 479, $526 \mathrm{p}$.

6. Salo d., Riwald S. Perfect preparation for swimming. Moscow.: Euro-management, 2015, 248.

7. Taormina Sh. Secrets of fast sailing for swimmers and triathletes. - M.: Mann, Ivanov and Ferber, 2013, 182p. 